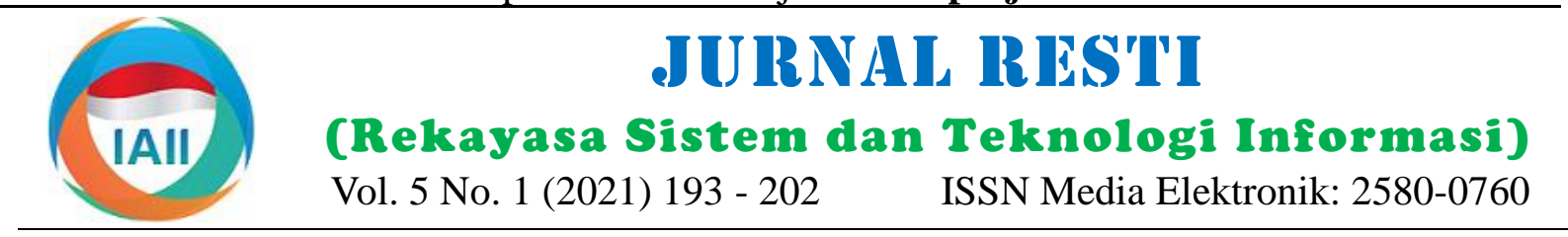

\title{
Pemantauan Perhatian Publik terhadap Pandemi COVID-19 melalui Klasifikasi Teks dengan Deep Learning
}

\author{
Novrindah Alvi Hasanah ${ }^{1}$, Nanik Suciati ${ }^{2}$, Diana Purwitasari ${ }^{3}$ \\ 1,2,3 Teknik Informatika, Fakultas Teknologi Elektro dan Informatika Cerdas, ITS Surabaya \\ 1alvinovrindah@gmail.com, ${ }^{2}$ nanik@if.its.ac.id, ${ }^{3}$ diana@if.its.ac.id
}

\begin{abstract}
Monitoring public concern in the surrounding environment to certain events is done to address changes in public behavior individually and socially. The results of monitoring public attention can be used as a benchmark for related parties in making the right policies and strategies to deal with changes in public behavior as a result of the COVID-19 pandemic. Monitoring public attention can be done using Twitter social media data because the users of the media are quite high, so that they can represent the aspirations of the general public. However, Twitter data contains varied topics, so a classification process is required to obtain data related to COVID-19. Classification is done by using word embedding variations (Word2Vec and fastText) and deep learning variations (CNN, RNN, and LSTM) to get the classification results with the best accuracy. The percentage of COVID-19 data based on the best accuracy is calculated to determine how high the public's attention is to the COVID-19 pandemic. Experiments were carried out with three scenarios, which were differentiated by the number of data trains. The classification results with the best accuracy are obtained by the combination of fasText and LSTM which shows the highest accuracy of $97.86 \%$ and the lowest of $93.63 \%$. The results of monitoring public attention to the time vulnerability between June and October show that the highest public attention to COVID-19 is in June.
\end{abstract}

Keywords: monitoring public concern, twitter, covid-19, word embedding, deep learning

\begin{abstract}
Abstrak
Memantau perhatian publik di lingkungan sekitar terhadap suatu kejadian tertentu dilakukan untuk mengatasi perubahan perilaku publik secara individual maupun sosial. Hasil pemantauan perhatian publik dapat dijadikan tolak ukur oleh pihakpihak terkait dalam membuat suatu kebijakan maupun strategi yang tepat untuk menghadapi perubahan perilaku publik sebagai efek pandemi COVID-19. Pemantauan perhatian publik dapat dilakukan menggunakan data media sosial Twitter karena pengguna media tersebut cukup tinggi, sehingga dapat mewakili aspirasi publik secara umum. Namun, data Twitter mengandung topik yang bervariasi sehingga diperlukan proses klasifikasi untuk mendapatkan data terkait COVID-19. Klasifikasi dilakukan dengan variasi word embedding (Word2Vec dan fastText) dan variasi deep learning (CNN, RNN, and LSTM) untuk mendapatkan hasil klasifikasi dengan akurasi terbaik. Data COVID-19 hasil klasifikasi berdasarkan akurasi terbaik dihitung prosentasenya untuk mengetahui seberapa tinggi perhatian publik terhadap pandemi COVID-19. Percobaan dilakukan dengan tiga skenario yang dibedakan oleh jumlah data train. Hasil klasifikasi dengan akurasi terbaik didapatkan oleh kombinasi fasText dan LSTM yang menunjukkan akurasi tertinggi sebesar 97.86\% dan terendah sebesar 93.63\%. Hasil pemantauan perhatian publik pada rentan waktu antara Bulan Juni sampai Bulan Oktober menunjukkan bahwa perhatian publik terhadap COVID-19 tertinggi adalah pada Bulan Juni.
\end{abstract}

Kata kunci: memantau perhatian publik, twitter, covid-19, word embedding, deep learning

\section{Pendahuluan}

Pemantauan perhatian publik di lingkungan sekitar terhadap suatu kejadian tertentu merupakan satu hal yang penting dilakukan. Selama ini, publik dengan mudah merubah perilaku individual maupun sosial saat menghadapi suatu masalah tertentu, termasuk COVID19. Wabah COVID-19 telah ditetapkan oleh organisasi kesehatan dunia atau yang disebut dengan World Health Organization (WHO) sebagai pandemi global. Pandemi COVID-19 menjadi salah satu topik penting yang menjadi perhatian khusus diseluruh dunia, termasuk di Indonesia khususnya Kota Surabaya. Hasil pemantauan perhatian publik dapat dijadikan tolak ukur oleh pihakpihak terkait untuk membuat suatu kebijakan maupun

Diterima Redaksi: 04-02-2021 | Selesai Revisi: 24-02-2021 | Diterbitkan Online: 28-02-2021 
strategi yang tepat dalam menghadapi perubahan Neural Network (RNN) dan Long-Short Term Memory perilaku publik sebagai efek menghadapi pandemi [1]. (LSTM).

Beberapa penelitian terdahulu menjelaskan pengaruh aktivitas bermedia sosial publik untuk pengambilan kebijakan oleh pihak-pihak terkait. Seperti pada penelitian [2] yang menjelaskan pentingnya sarana dan prasarana untuk membuat kebijakan publik, salah satunya adalah feedback publik yang didapatkan melalui media sosial. Penelitian lainnya yaitu penelitian [3] yang menganalisis feedback publik mengenai 100 hari pertama sistem pemerintahan baru DKI Jakarta. Hal ini digunakan untuk melihat seberapa puas publik mengenai Namun, penelitian [13] menunjukkan bahwa RNN lebih perubahan sistem pemerintahan baru DKI Jakarta. baik dari CNN. Hal ini dikarenakan RNN dapat menjaga Penelitian lainnya yaitu [4] menganalisis komunikasi urutan urutan kata [11]. RNN memprediksi kata politik melalui media sosial yaitu Twitter sebagai solusi berikutnya dalam sebuah kalimat karena kemampuan partisipasi masyarakat, sosialisasi komunikatif, dan untuk menangkap informasi konstekstual yang baik ruang diskusi yang terbuka. Pada penelitian tersebut dalam sekuens [14][15]. RNN memiliki permasalahan objek penelitian merupakan akun Twitter Walikota yaitu gradient exploding atau vanishing. Sehingga Bandung saat itu yaitu Ridwan Kamil.

Pemantauan perhatian publik dapat dilakukan melalui data media sosial Twitter. Hal tersebut karena pengguna media sosial di Indonesia cukup tinggi. Sehingga, media sosial dinilai dapat mewakili aspirasi publik secara umum. Selama ini publik cenderung meluapkan isi hati dan berbagi informasi melalui media sosial [5][6]. Akun Twitter terverifikasi menjadi akun popular yang dimanfaatkan publik untuk mendapatkan informasi mengenai berbagai macam masalah termasuk pandemi COVID-19. Salah satu akun Twitter terverifikasi di Surabaya yang sering menjadi tempat rujukan masyarakat untuk mendapatkan berbagai macam informasi di wilayah Surabaya adalah akun Twitter Suara Surabaya. Suara Surabaya merupakan akun radio berbasis Twitter yang selalu meng-update kejadian di wilayah Surabaya dan sekitarnya.

Namun, teks Twitter memiliki kendala jika digunakan sebagai dasar untuk memantau perhatian publik pada topik tertentu. Teks Twitter memiliki panjang teks yang terbatas dan mengandung topik yang bervariasi, sehingga sulit digunakan untuk mendeteksi satu topik tertentu misalnya pandemi COVID-19. Kendala tersebut menyebabkan dibutuhkannya proses klasifikasi untuk mengetahui seberapa tinggi perhatian publik terhadap topik COVID-19.

Klasifikasi teks sebenarnya telah banyak dilakukan dengan berbagai macam metode. Namun, klasifikasi teks menggunakan deep learning dinilai lebih baik dari machine learning [7]. Hal tersebut dibuktikan dengan penelitian terdahulu yang telah dilakukan seperti penelitian [7][8] yang menunjukkan bahwa nilai recall, f-measure dan precision lebih tinggi dari beberapa penelitian sebelumnya yang menggunakan machine learning saat diaplikasikan pada objek yang sama. Berbagai macam metode deep learning yang digunakan peneliti terdahulu untuk klasifikasi teks yaitu Convolutional Neural Network (CNN), Recurrent
Penelitian [7][9][10] membuktikan bahwa CNN menunjukkan hasil yang baik saat digunakan pada objek teks. CNN sebagian besar memiliki jumlah parameter yang lebih kecil, sehingga CNN dapat dilatih dengan sejumlah kecil data kata [11]. Kelebihan CNN lainnya untuk klasifikasi teks adalah filter konvolusional yang dapat mempelajari fitur yang cocok pada tugas yang dapat mempelajari fitur yang
diberikan secara otomatis [12].

metode RNN dikembangkan menjadi suatu metode RNN modern yang disebut LSTM. Selain mengatasi masalah pada RNN standar, LSTM juga mempelajari dependensi jangka panjang dari urutan representasi tingkat lebih tinggi yang baik jika dibandingkan dengan model lainnya [16]. Hal tersebut yang menyebabkan LSTM dapat mengatasi masalah yang dialami oleh RNN standar. Penelitian terdahulu yang memanfaatkan LSTM sebagai metode klasifikasi teks adalah penelitian [17][18] yang menunjukkan bahwa LSTM memiliki kinerja yang lebih unggul dari CNN dan RNN standar.

Penelitian ini memanfaatkan word embedding sebagai metode ekstraksi fitur yang dikombinasikan dengan metode deep learning. Dua metode word embedding yang digunakan dalam ujicoba yaitu Word2Vec dan fastText. Hal tersebut berdasarkan penelitian [18][10][19] yang memanfaatkan metode tersebut sebagai ekstraksi fitur dan menunjukkan hasil yang unggul jika dibandingkan dengan metode deep learning tanpa word embedding. Dari berbagai literatur tersebut maka penelitian ini akan membandingkan kinerja variasi deep learning (CNN, RNN, dan LSTM) yang dikombinasikan dengan variasi word embedding (Word2Vec dan fastText).

Penelitian ini berfokus untuk memantau perhatian publik terhadap pandemi COVID-19 berdasarkan teks Twitter di area Surabaya. Namun, variasi topik pada teks Twitter menyebabkan sulitnya fokus pada satu topik tertentu sehingga membutuhkan proses klasifikasi. Oleh karena itu, penelitian ini mengusulkan pemantauan perhatian publik berdasarkan teks Twitter dengan klasifikasi teks menggunakan variasi deep learning dan variasi word embedding. Penelitian kami dapat menujukkan kombinasi metode mana yang memiliki nilai akurasi terbaik. Hasil klasifikasi dengan akurasi terbaik dihitung untuk mengetahui perhatian publik terhadap pandemi COVID-19. Objek penelitian merupakan akun Twitter Suara Surabaya. Pemantauan perhatian publik dilakukan dalam rentan waktu antara Bulan Juni sampai Bulan 


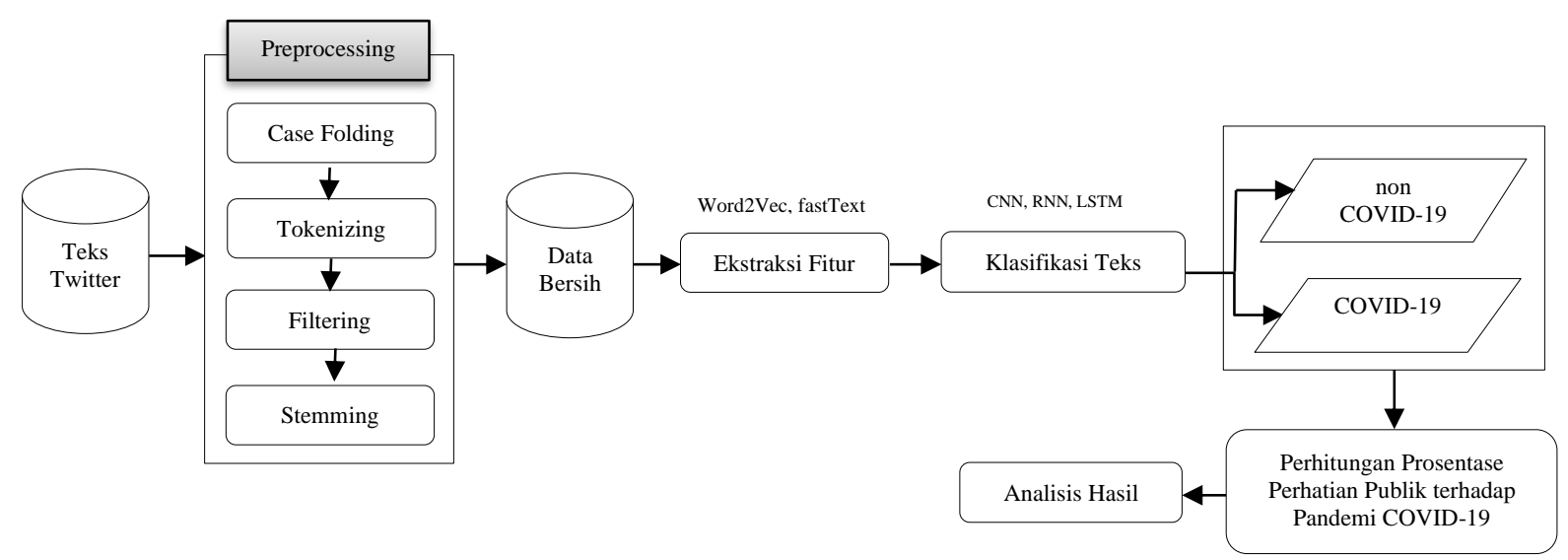

Gambar 1. Tahapan Proses Pemantauan Perhatian Publik berdasarkan Hasil Klasifikasi Teks Twitter

Tabel 1. Preprocessing Data Teks Twitter Suara Surabaya

\begin{tabular}{|c|c|c|c|c|}
\hline Teks Kotor & Output Case Folding & $\begin{array}{c}\text { Output } \\
\text { Tokenizing }\end{array}$ & $\begin{array}{c}\text { Output } \\
\text { FIltering }\end{array}$ & $\begin{array}{c}\text { Output } \\
\text { Stemming }\end{array}$ \\
\hline $\begin{array}{l}\text { Heru Tjahjono Sekretaris Daerah } \\
\text { Provinsi Jawa Timur Rabu (29/4/2020) } \\
\text { mengabarkan hasil dari evaluasi PSBB } \\
\text { hari pertama di sektor dunia kerja. }\end{array}$ & $\begin{array}{l}\text { heru tjahjono sekretaris daerah provinsi } \\
\text { jawa timur rabu mengabarkan hasil dari } \\
\text { evaluasi psbb hari pertama di sektor } \\
\text { dunia kerja }\end{array}$ & $\begin{array}{l}\text { heru } \\
\text { tjahjono } \\
\text { sekretaris } \\
\text { daerah } \\
\text { provinsi } \\
\text { jawa } \\
\text { timur } \\
\text { rabu } \\
\text { mengabarkan } \\
\text { hasil } \\
\text { evaluasi } \\
\text { psbb } \\
\text { hari } \\
\text { pertama } \\
\text { di } \\
\text { sektor } \\
\text { dunia } \\
\text { kerja }\end{array}$ & $\begin{array}{l}\text { heru } \\
\text { tjahjono } \\
\text { sekretaris } \\
\text { daerah } \\
\text { provinsi } \\
\text { jawa } \\
\text { timur } \\
\text { rabu } \\
\text { mengabarkan } \\
\text { hasil } \\
\text { evaluasi } \\
\text { psbb } \\
\text { hari } \\
\text { pertama } \\
\text { sektor } \\
\text { dunia } \\
\text { kerja }\end{array}$ & $\begin{array}{l}\text { heru } \\
\text { tjahjono } \\
\text { sekretaris } \\
\text { daerah } \\
\text { provinsi } \\
\text { jawa } \\
\text { timur } \\
\text { rabu } \\
\text { kabar } \\
\text { hasil } \\
\text { evaluasi } \\
\text { psbb } \\
\text { hari } \\
\text { pertama } \\
\text { sektor } \\
\text { dunia } \\
\text { kerja }\end{array}$ \\
\hline
\end{tabular}

Oktober. Hasil dari pemantauan perhatian publik dapat 2.2. Praposes Data

dijadikan pihak terkait dalam membangun kebijakan-

kebijakan dan strategi tanggap darurat yang tepat untuk menghadapi perubahan perilaku publik sebagai efek pandemi.

\section{Metode Penelitian}

Penelitian ini melakukan beberapa tahap dalam proses pemantauan perhatian publik terhadap pandemi COVID-19 berdasarkan hasil klasifikasi yang ditunjukkan pada Gambar 1. Setiap langkah dijelaskan pada sub-bab berikut.

\subsection{Persiapan Data}

Dataset yang digunakan berupa teks Twitter yang didapatkan dari timeline akun Twitter Suara Surabaya mulai dari Bulan Februari 2020 sampai Bulan Oktober 2020. Dataset dikumpulkan dengan teknik crawling data menggunakan Twitter API yang disimpan ke dalam format .csv. Data yang berhasil dikumpulkan lebih dari 12000 data yang terdiri dari tweet dan retweet di timeline akun Twitter Suara Surabaya.
Data yang telah berhasil dikumpulkan di-preprocessing untuk menghilangkan noise yang tidak dibutuhkan pada proses klasifikasi. Terdapat beberapa tahap preprocessing data yang digunakan pada penelitian ini, yaitu:

1. Case Folding. Tahap ini merupakan sebuah proses untuk merubah semua huruf kapital menjadi huruf kecil atau lowercase. Teks Twitter merupakan teks bebas yang dapat memuat berbagai macam topik dengan berbagai macam bentuk tulisan sesuai dengan apa yang ingin ditulis oleh penggunanya. Sehingga banyak sekali kata yang mengandung huruf besar dan huruf kecil. Selain itu, pada proses case folding semua tanda baca seperti koma, titik, tanda seru, tanda tanya dan lain sebagainya serta angka dan semua karakter lain selain huruf dihilangkan.

2. Tokenizing. Pada proses ini setiap kata yang ada pada setiap kalimat dipisahkan.

3. Filtering. Proses ini adalah suatu proses mengambil kata-kata yang dianggap penting dari hasil tokenizing dan membuang stopword atau kata sambung seperti 
Tabel 2. Label Data Teks Twitter Suara Surabaya

\begin{tabular}{lll}
\hline \multicolumn{2}{c}{ Teks Kotor } & \multicolumn{1}{c}{ Output Preprocessing } \\
\hline $\begin{array}{l}\text { Heru Tjahjono Sekretaris Daerah Provinsi Jawa Timur Rabu } \\
(29 / 4 / 2020) \text { mengabarkan hasil dari evaluasi PSBB hari }\end{array}$ & $\begin{array}{l}\text { heru tjahjono sekretaris daerah provinsi jawa timur rabu } \\
\text { mengabarkan hasil dari evaluasi psbb hari pertama di } \\
\text { sektor dunia kerja }\end{array}$ \\
\hline Pertama di sektor dunia kerja. & pelaku usaha kena sanksi langgar psbb \\
\hline Kecelakaan di MERR Surabaya, satu orang jadi korban. & kecelakaan merr surabaya satu orang korban \\
\hline $\begin{array}{l}\text { Perempuan paruh baya meninggal di rumah kontrakannya di } \\
\text { Patmosusastro. }\end{array}$ & $\begin{array}{l}\text { perempuan paruh baya meninggal rumah kontrakan } \\
\text { patmosusastro }\end{array}$ & 0 \\
\hline
\end{tabular}

Tabel 3. Skenario Uji Coba Klasifikasi Teks Twitter Suara Surabaya

\begin{tabular}{cll}
\hline Skenario & Train Data & Test Data \\
\hline \multirow{3}{*}{1} & April-Mei & Juni \\
& Mei-Juni & Juli \\
& Juni-Juli & Agustus \\
& Juli-Agustus & September \\
& Agustus-September & Oktober \\
\hline \multirow{3}{*}{2} & Maret-April-Mei & Juni \\
& April-Mei-Juni & Juli \\
& Mei-Juni-Juli & Agustus \\
& Juni-Juli-Agustus & September \\
& Juli-Agustus-September & Oktober \\
\hline \multirow{3}{*}{3} & Februari-Maret-April-Mei & Juni \\
& Maret-April-Mei-Juni & Juli \\
& April-Mei-Juni-Juli & Agustus \\
& Mei-Juni-Juli-Agustus & September \\
& Juni-Juli-Agustu-September & Oktober \\
\hline
\end{tabular}

“yang”, “dan”, “di”, “dari”, “adalah”, dan lain sebagainya.

4. Stemming. Proses ini adalah proses mengubah kata berimbuhan menjadi kata dasar. Penelitian ini menggunakan library sastrawi karena dataset yang digunakan merupakan dataset berbahasa Indonesia.

Contoh tahap preprocessing data dengan dataset yang diambil dari timeline akun Suara Surabaya ditunjukkan pada Tabel 1. Tabel tersebut menunjukkan teks asli yang didapatkan dari akun Twitter Suara Surabaya dan diproses melalui tahap case folding, tokenizing, filtering, dan stemming. Dataset bersih hasil preprocessing dibedakan menjadi data train dan data test. Dataset yang menjadi data train diberi label secara manual untuk digunakan pada proses klasifikasi. Data diberi label dua kelas, data yang berlabel " 0 " merupakan data non COVID-19 dan data yang belabel " 1 " merupakan data COVID-19. Contoh data yang telah diberi label secara manual setelah preprocessing data ditunjukkan pada Tabel 2.

Dataset yang telah melalui tahap praproses dibagi ke dalam dua jenis yaitu data train dan data test yang masing-masing digunakan untuk melatih dan menguji model arsitektur klasifikasi yang dibangun. Eksperimen dilakukan dengan tiga skenario yang dibedakan oleh jumlah data train. Hal tersebut digunakan untuk membuktikan pengaruh jumlah data train pada proses klasifikasi teks. Skenario tersebut ditunjukkan pada Tabel 3. Pada skenario 1, data train menggunakan data dua bulan, skenario 2 menggunakan data 3 bulan, dan skenario 3 menggunakan data 4 bulan. Sedangkan data test yang digunakan adalah data Bulan Juni, Juli, Agustus, September, dan Oktober.

\subsection{Ekstraksi Fitur dengan Word Embedding}

Metode word embedding yang digunakan untuk proses ekstraksi fitur adalah Word2Vec dan fastText. Penjelasan dari setiap metode tersebut dijelaskan pada poin-poin berikut.

\subsubsection{Word2Vec}

Word2Vec adalah salah satu metode word embedding pada package gensim. Beberapa kasus klasifikasi pada Word2Vec menunjukkan bahwa kata yang sama akan memiliki vektor yang sama [20]. Word2Vec dinilai efektif digunakan untuk ektraksi fitur, namun memiliki kelemahan yaitu tidak dapat membedakan tingkat kepentingan suatu kata karena memperlakukan setiap kata secara sama, sehingga menjadi sulit untuk mengekstraksi kata yang memiliki nilai lebih tinggi daripada yang lainnya [21].

Penelitian ini memanfaatkan pre-train Bahasa Indonesia. Panjang dimensi yang digunakan adalah 300 dimensi yang berguna untuk menentukan seberapa banyak informasi yang didapatkan. Semakin kecil panjang dimensi maka akan semakin sedikit informasi yang didapatkan karena banyaknya informasi yang terbuang. Hal ini akan mempengaruhi proses klasifikasi. Setiap kata yang ada pada dataset diubah menjadi vektor sesuai dengan pre-train Word2Vec. Setiap kalimat ditambahkan fungsi padding untuk menyelaraskan panjang matriks input setiap kalimat. Hasil matriks digunakan sebagai input pada model deep learning.

Word2Vec menyediakan dua model yaitu Continous Bag-Of-Word (CBOW) dan Skip-gram. Input pada model Skip-gram berupa current word yang berguna untuk meprediksi konteks disekitar. Skip-gram mempelajari probabilitas dari kata-kata didalam konteks. Pada model skip-gram, setiap kata harus diubah menjadi one-hot encode vectors. Cara kerja skip-gram diilustrasikan pada Gambar 2. Pada ilustrasi tersebut, kata "pandemi" berperan sebagai input. Sedangkan yang menjadi target adalah kata "covid" "masuk" "wilayah" "indonesia". Ketika output telah didapatkan, cross entropy digunakan untuk memperhitungkan nilai error. 


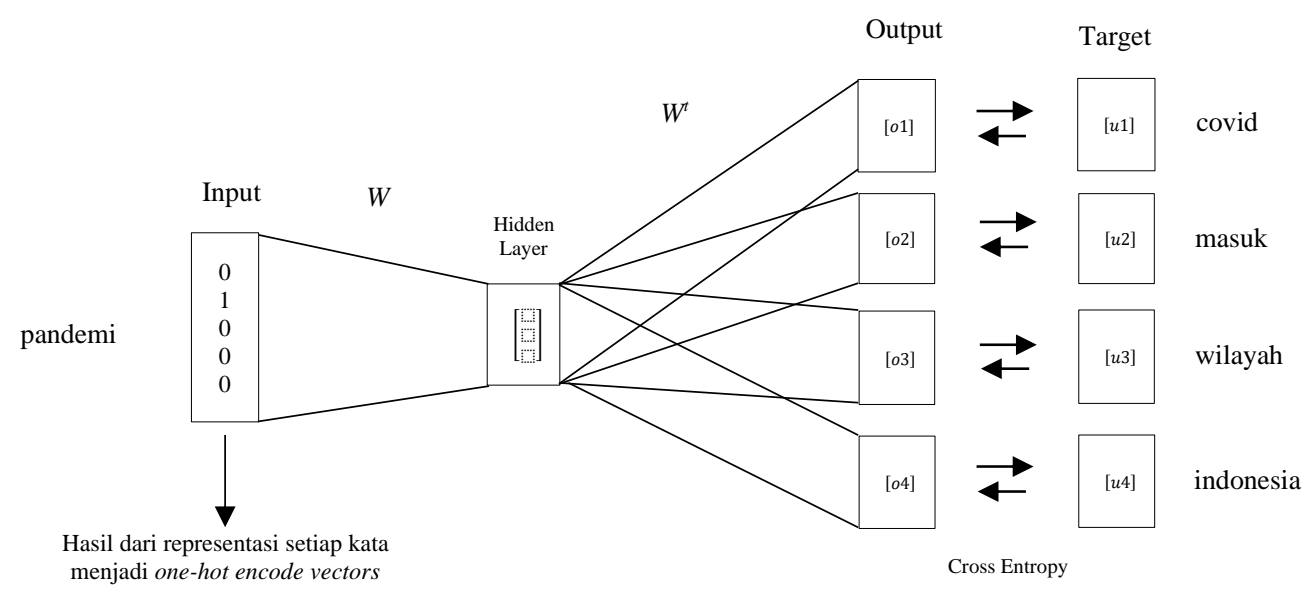

Gambar 2. Skip-Gram Model pada Teks Twitter COVID-19

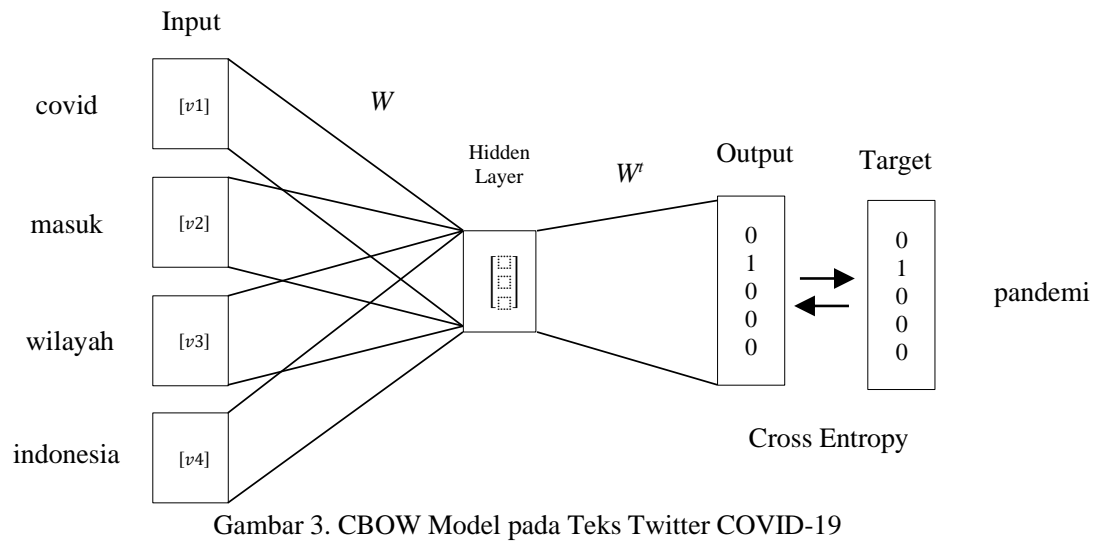

Sedangkan model CBOW bekerja untuk meprediksi Model fastText yang digunakan adalah model pre-train current word dengan input merupakan konteks Bahasa Indonesia dengan panjang dimensi sebesar 300 disekitarnya. Konteks yang digunakan sama dengan dimensi. Pre-train word embedding merupakan model skip-gram yaitu menggunakan one-hot-encode sekumpulan word embedding yang sudah pernah dilatih vectors. Hal tersebut dikarenakan kinerja model CBOW untuk domain yang besar pada case study tertentu merupakan kebalikan dari model skip-gram. Ilustrasi sehingga dapat dimanfaatkan untuk menyelesaikan kinerja model CBOW ditunjukkan pada Gambar 3. Pada permasalahan yang sama. Pada dasarnya suatu teks tidak ilustrasi tersebut, kata "covid" "masuk" "wilayah" dapat diproses deep learning jika bentuknya bukan "indonesia" berperan sebagai input. Sedangkan target vektor. Sehingga word embedding berfungsi untuk adalah kata "pandemi". Pada model CBOW juga merepresentasikan teks kedalam vektor agar dapat memperhitungkan nilai error dengan menggunakan diproses deep learning.

cross entropy.

\subsection{2 fastText}

\subsection{Klasifikasi Teks dengan Deep Learning}

Proses klasifikasi teks menerapkan variasi deep learning fastText adalah toolkit yang dikembangkan oleh tim yaitu CNN, RNN, dan LSTM. Metode deep learning peneliti Facebook [22]. fastText merupakan dikombinasikan dengan metode word embedding untuk pengembangan dari model Word2 Vec yang mendapatkan pasangan kombinasi dengan hasil akurasi mempresentasikan setiap kata sebagai kantong karakter terbaik pada setiap skenario ujicoba. Setiap metode word n-gram [23]. fastText memiliki kelebihan yaitu mampu embedding telah dijelaskan pada sub bab sebelumnya. meningkatkan representasi kata untuk bahasa yang kaya Sedangkan untuk metode deep learning yang digunakan secara morfologis yang mengandung kata kerja dan kata dijelaskan pada setiap poin berikut.

benda dalam berbagai bentuk [24]. fastText dapat meningkatkan kinerja pada tugas-tugas sintaksis secara signifikan tetapi tidak banyak pada semantik [19].

\subsubsection{CNN (Convolutional Neural Network)}

Arsitekttur CNN yang digunakan pada penelitian ini ditunjukkan pada Gambar 4. Arsitektur tersebut terdiri 


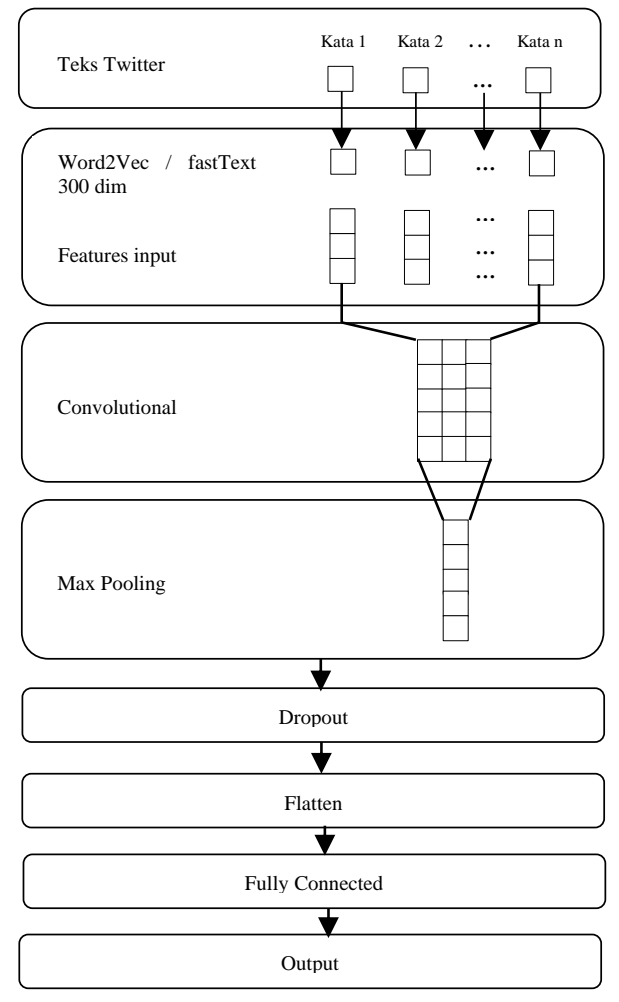

Gambar 4. Arsitektur CNN

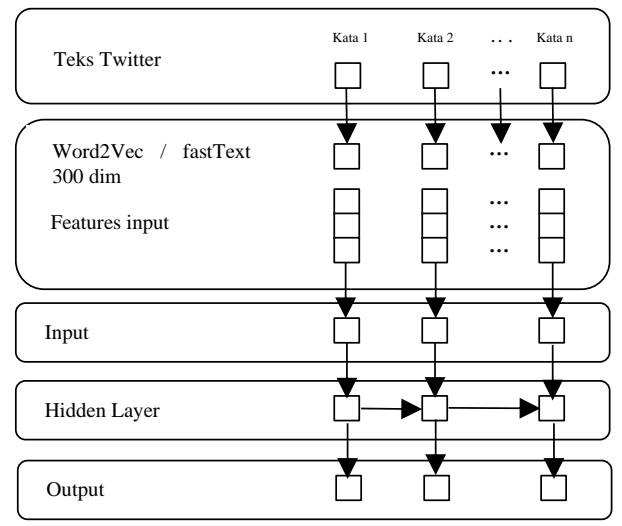

Gambar 5. Arsitektur RNN

convolutional layer. Pada layer ini terdapat beberapa parameter yang digunakan yaitu Maxpooling2D, sequence_length, ukuran filter dan strides.

Pada fully connected layer terdapat parameter reshape yang berfungsi untuk merubah feature map menjadi sebuah vektor. Vektor tersebut terhubung dengan output layer untuk dilakukan klasifikasi. Pada layer ini parameter aktivasi menggunakan fungsi sigmoid karena klasifikasi merupakan klasifikasi biner atau klasifikasi dua kelas. Parameter lainnya yaitu "loss" yang menggunakan fungsi categorical_crossentropy.

Terakhir yaitu code untuk melatih model CNN yang telah dibangun. Arsitektur $\mathrm{CNN}$ dilatih dengan parameter batch_size sebesar 128 dan proses iterasi epoch sebesar 50 untuk mendapatkan akurasi yang baik. Fungsi optimasi yang digunakan adalah "adam". Sedangkan untuk parameter metric yang berfungsi menyimpan hasil evaluasi berupa "accuracy".

\subsubsection{RNN (Recurrent Neural Network)}

Model Arsitektur RNN ditunjukkan pada Gambar 5. Arsitektur RNN memproses data input dari inputan satu sampai inputan ke- $n$ satu persatu secara sekuensial. Setiap inputan akan diteruskan dari hidden layer satu ke hidden layer selanjutnya sampai pada hasil output. RNN bekerja dengan proses looping. Misalnya untuk mencari output dari input berupa huruf "p", “a”, “n”, “d”, “e”, "m" maka setiap input akan diproses pada hidden layer untuk memprediksi output yang seharusnya muncul setelah input " $\mathrm{m}$ ". RNN tidak membuang informasi sebelumnya namun menyimpan dan memproses pada hidden layer. Dalam contoh ini, prediksi output yang tepat ialah huruf "i”, sehingga akan menjadi kata yang sempurna yaitu "pandemi".

Tiga layer utama pada RNN adalah input layer, hidden layer, dan output layer. Penelitian ini menggunakan RNN sebesar 100 unit/cell dengan dropout sebesar 0.4 yang artinya secara random tidak mengaktifkan $40 \%$ neuron pada testing. Panjang sekuens menyesuaikan panjang data train. Aktivasi yang dipakai adalah fungsi sigmoid. Pada fungsi kompilasi, terdapat parameter 


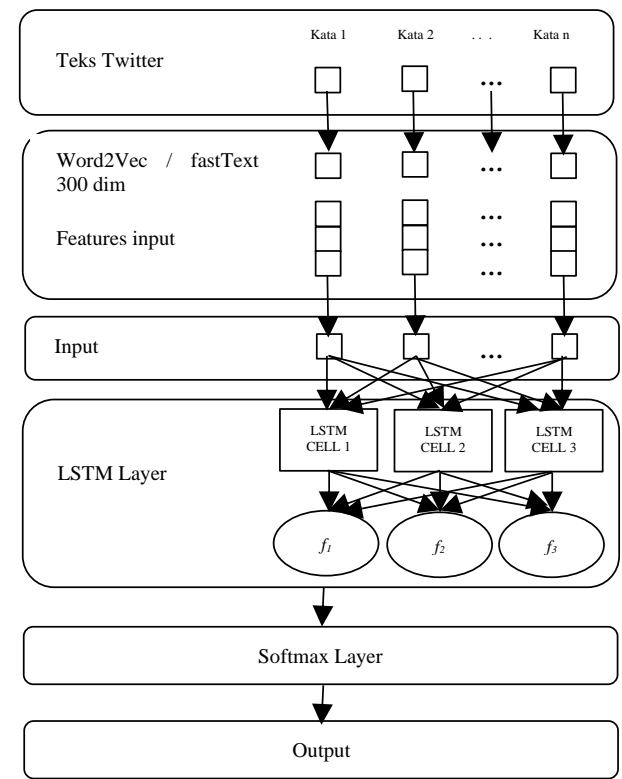

Gambar 6. Arsitektur LSTM

loss=categorical_crossentropy. Sedangkan optimizer menggunakan "adam". Model RNN dilatih dengan batch_size sebesar 128 dan panjang epoch 50.

\subsubsection{LSTM (Long-Short Term Memory)}

Model arsitektur LSTM ditunjukkan pada Gambar 6. Arsitektur LSTM yang dibangun terdiri dari beberapa layer yaitu input layer, LSTM layer, dan output layer. Sebenarnya, arsitektur LSTM tidak jauh berbeda dengan RNN. Namun LSTM dapat mengkomputasikan hidden state yang dapat menyimpan long-term dependencies. Sehingga, LSTM dapat menyempurnakan kinerja RNN yang mengalami permasalahan gradient exploding atau vanishing pada RNN standar.

Teks Twitter diproses dengan metode word embedding yaitu Word2Vec maupun fastText dengan panjang dimensi 300. Hasil representasi vektor kata dimasukkan ke input layer. Panjang sekuens menyesuaikan dengan data train yang digunakan setiap kali ujicoba dilakukan sesuai skenario yang mengacu pada Tabel 2. Model yang digunakan pada arsitektur LSTM adalah model sequential. Model sequential ini berfungsi untuk tempat menumpuk lapisan LSTM. Sequential merupakan perintah pertama yang digunakan untuk menginisiasi bentuk dasar RNN. Layer LSTM menggunakan ukuran cell/unit sepanjang 100 cell dan dropout dengan rate 0.4 yang artinya akan menonaktifkan secara random $40 \%$ neuron selama fase testing. Fungsi optimasi menggunakan "adam" dan fungsi loss menggunakan categorical_crossentropy. Output berupa hasil akurasi dari proses klasifikasi dua kelas yaitu COVID-19 dan non COVID-19. Arsitektur LSTM dilatih dengan panjang epoch sebesar 50 kali yang artinya data training
diulang sebanyak 50 kali agar mendapatkan hasil akurasi maksimal. batch_size menggunakan ukuran 128 .

\subsection{Pemantauan Perhatian Publik}

Pemantauan perhatian publik dilakukan melalui perhitungan prosentasi data hasil klasifikasi teks terkait COVID-19 dengan akurasi terbaik. Perhitungan dilakukan menggunakan rumus prosentase seperti yang ditunjukkan pada Rumus 1.

$P P_{t}=\frac{\sum \text { tweet CoVID-19 }}{\sum \text { semua tweet }} \times 100 \%$

dengan $P P_{t}$ merupakan perhatian publik pada waktu tertentu. Pada penelitian ini pemantauan perhatian publik dilakukan setiap bulan, dimulai dari Bulan Juni sampai Bulan Oktober. Data tweet terkait COVID-19 yang didapatkan melalui klasifikasi teks dibagi dengan semua data dan dikalikan $100 \%$. Perhitungan tersebut menunjukkan prosentase tweet pada timeline akun Twitter Suara Surabaya terkait COVID-19 untuk bulan tertentu.

\section{Hasil dan Pembahasan}

\subsection{Klasifikasi Teks Twitter}

Pemantauan perhatian publik melalui media sosial dilakukan dengan proses klasifikasi teks. Hal ini disebabkan karena Twitter memiliki topik yang bervariasi. Klasifikasi dilakukan dengan variasi beberapa metode word embedding dan deep learning. Metode word embedding yang digunakan adalah Word2Vec dan fastText. Sedangkan metode deep learning yang digunakan adalah $\mathrm{CNN}$, RNN, dan LSTM. Hal ini dilakukan untuk menemukan kombinasi metode terbaik yang dapat diterapkan dalam klasifikasi teks. Eksperimen dilakukan dengan tiga skenario berbeda untuk membuktikan pengaruh jumlah data train yang berbeda jika digunakan untuk melatih data test yang sama. Skenario 1 menggunakan data train dengan data dua bulan. Skenario 2 menggunakan data train dengan data tiga bulan. Dan skenario 3 menggunakan data train dengan data empat bulan. Setiap data test dilatih dengan data train dari tiga skenario berbeda. Misalnya, data Bulan Juni dilatih dengan tiga skenario berbeda sesuai dengan data train yang telah ditunjukkan Tabel 3 pada bagian metode penelitian. Data test lainnya juga dilatih dengan menggunakan tiga skenario yang berbeda. Sehingga, hasil klasifikasi dapat menunjukkan pengaruh perbedaan jumlah data train jika digunakan untuk melatih data test yang sama.

Hasil klasifikasi ditunjukkan pada Tabel 4. Pada tabel tersebut, kolom "W2V" adalah hasil akurasi yang diperoleh metode deep learning yang dikombinasikan dengan metode word embedding Word2Vec. Sedangkan kolom "FT" adalah hasil akurasi yang diperoleh metode deep learning yang dikombinasikan dengan menggunakan metode word embedding fastText. Pada hasil klasifikasi, ketiga skenario menunjukkan bahwa kombinasi metode fastText dan LSTM meraih akurasi terbaik jika dibandingkan dengan hasil dari pasangan 
Tabel 4. Akurasi Hasil Klasifikasi Teks Twitter setiap Skenario

\begin{tabular}{|c|c|c|c|c|c|c|c|c|}
\hline \multirow[b]{2}{*}{ Skenario } & \multirow[b]{2}{*}{ Train Data } & \multirow[b]{2}{*}{ Test Data } & \multicolumn{2}{|c|}{$\mathrm{CNN}$} & \multicolumn{2}{|c|}{ RNN } & \multicolumn{2}{|c|}{ LSTM } \\
\hline & & & $\begin{array}{c}\mathrm{W} 2 \mathrm{~V} \\
(\%)\end{array}$ & $\begin{array}{l}\text { FT } \\
(\%) \\
\end{array}$ & $\begin{array}{c}\mathrm{W} 2 \mathrm{~V} \\
(\%)\end{array}$ & $\begin{array}{l}\text { FT } \\
(\%) \\
\end{array}$ & $\begin{array}{c}\text { W2V } \\
(\%)\end{array}$ & $\begin{array}{l}\text { FT } \\
(\%) \\
\end{array}$ \\
\hline \multirow{5}{*}{1} & April-Mei & Juni & 89.22 & 89.88 & 92.19 & 94.46 & 93.44 & 95.15 \\
\hline & Mei-Juni & Juli & 88.37 & 88.26 & 91.50 & 94.26 & 93.07 & 94.76 \\
\hline & Juni-Juli & Agustus & 86.70 & 87.07 & 91.06 & 93.71 & 91.86 & 93.96 \\
\hline & Juli-Agustus & September & 87.81 & 88.37 & 91.27 & 94.06 & 92.05 & 94.68 \\
\hline & Agustus-September & Oktober & 85.31 & 86.15 & 90.64 & 92.96 & 88.87 & 93.63 \\
\hline \multirow{5}{*}{2} & Maret-April-Mei & Juni & 91.24 & 91.63 & 92.86 & 95.17 & 94.49 & 95.93 \\
\hline & April-Mei-Juni & Juli & 91,06 & 90.99 & 92.92 & 94.82 & 94.41 & 95.81 \\
\hline & Mei-Juni-Juli & Agustus & 90.03 & 90.66 & 92.60 & 94.73 & 94.09 & 95.33 \\
\hline & Juni-Juli-Agustus & September & 89.22 & 90.02 & 92.41 & 94.67 & 94.05 & 95.17 \\
\hline & Juli-Agustus-September & Oktober & 89.01 & 88.81 & 92.10 & 94.40 & 92.86 & 95.14 \\
\hline \multirow{5}{*}{3} & Februari-Maret-April-Mei & Juni & 93.29 & 93.57 & 96.54 & 97.53 & 96.71 & 97.86 \\
\hline & Maret-April-Mei-Juni & Juli & 92.04 & 92.69 & 95.10 & 96.27 & 95.80 & 97.09 \\
\hline & April-Mei-Juni-Juli & Agustus & 91.46 & 92.31 & 94.52 & 95.82 & 94.65 & 96.34 \\
\hline & Mei-Juni-Juli-Agustus & September & 91.43 & 92.23 & 93.20 & 95.34 & 94.51 & 96.15 \\
\hline & Juni-Juli-Agustus-September & Oktober & 90.28 & 90.79 & 92.74 & 94.77 & 90.28 & 95.69 \\
\hline
\end{tabular}

Word2Vec dan LSTM serta semua pasangan metode seperti pada teks Twitter. Sehingga, jika LSTM CNN dan RNN. Klasifikasi dengan hasil akurasi terbaik diaplikasikan untuk memproses dataset berupa teks digunakan untuk pemantauan perhatian publik. Pada Twitter maka LSTM dinilai sangat cocok.

Tabel 4 kolom LSTM dengan menggunakan metode word embedding fastText akan dijadikan untuk pemantauan perhatian publik karena meraih hasil akurasi tertinggi dari semua ujicoba yang telah dilakukan.

Hasil akurasi tertinggi dari semua skenario diperoleh skenario 3. Skenario 3 merupakan skenario dengan jumlah data train terbanyak. Misalnya, hasil klasifikasi data Bulan Juni menunjukkan hasil akurasi skenario 3 yang diklasifikasi dengan menggunakan LSTM dan Hasil akurasi menunjukkan bahwa fastText lebih unggul fastText sebesar $97.86 \%$. Sedangkan, untuk skenario 1 dari Word2Vec. fastText merupakan bentuk terbaru dari dan 2 hanya mencapai akurasi sebesar $95.15 \%$ dan pengembangan metode Word2Vec [23][22]. fastText 95.93\%. Hasil akurasi skenario 2 lebih tinggi jika dapat melatih dataset dengan ukuran yang besar seperti dibandingkan dengan hasil akurasi dengan pada penelitian ini yang memiliki dataset lebih dari menggunakan skenario 1. Begitupun untuk hasil 12000 data. fastText juga dapat memberikan klasifikasi data Bulan Juli, Agustus, September, dan representasi kata yang tidak muncul dalam test data. Oktober. Hal ini membuktikan bahwa semakin banyak Representasi kata fastText yaitu dengan cara data train yang digunakan maka semakin baik pula hasil mengasumsikan sebuah kata dikomposisikan oleh $n$ - yang didapatkan.

gram karakter, panjang $n$ dapat berubah. Untuk lebih simple-nya, fastText bekerja apabila suatu kata tidak muncul selama training model, maka kata tersebut dapat dipecah menjadi $n$-gram agar vektor dari kata dapat keluar.

Namun, pada setiap skenario hasil akurasi yang ditunjukkan pada skenario yang memiliki unsur Bulan September menunjukkan hasil yang lebih rendah. Hal ini disebabkan karena dataset yang berhasil dikumpulkan pada Bulan September dari timeline akun Twitter Suara

Dari semua ujicoba, metode LSTM mengungguli semua Surabaya hanya sekita 500 data. Berbeda dengan data metode deep learning yang digunakan yaitu RNN dan yang berhasil didapatkan pada bulan lainnya yang CNN. Hasil ujicoba ini sama dengan hasil penelitian [17] mencapai lebih dari 1000 data. Hal tersebut yang menunjukkan bahwa LSTM lebih baik jika membuktikan semakin banyak data maka kinerja deep dibandingkan dengan CNN dan RNN. CNN dinilai lebih learning akan semakin baik karena deep learning baik jika diaplikasikan pada objek gambar. Sehingga bekerja secara maksimal untuk dataset yang besar. jika dibandingkan dengan RNN dan LSTM untuk mengatasi objek teks, kinerja CNN tidak cukup baik. 3.2. Pemantauan Perhatian Publik

LSTM merupakan bentuk modern dari RNN. LSTM Pemantauan perhatian publik dilakukan dengan dapat mengatasi masalah gradient exploding atau menghitung data tweet terkait COVID-19 yang vanishing pada RNN standar. LSTM juga dapat didapatkan melalui klasifikasi teks dengan hasil akurasi mempelajari dependensi jangka panjang dari urutan terbaik sesuai dengan Rumus 1 yang telah disebutkan representasi tingkat yang lebih tinggi lebih baik daripada pada bab metode penelitian. Prosentase perhatian publik model lainnya [16]. Menurut [18][25] metode LSTM terhadap pandemi COVID-19 melalui klasifikasi teks lebih unggul bila digunakan untuk model deret waktu Twitter menunjukkan bahwa semua skenario 


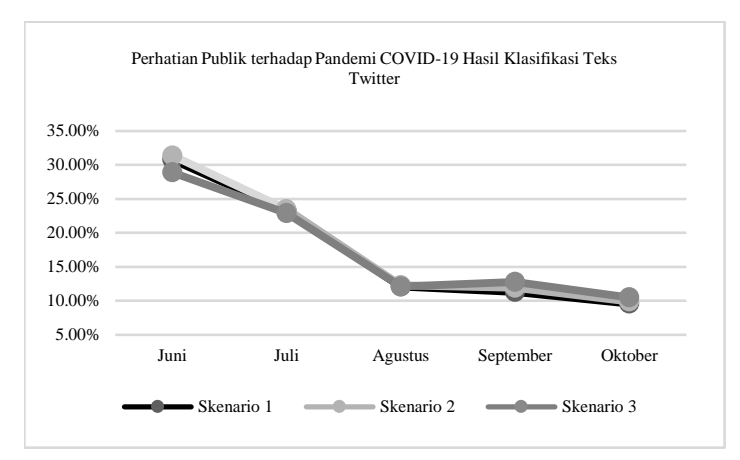

Gambar 7. Perhatian Publik terhadap Pandemi COVID-19 dari Hasil Klasifikasi Teks Twitter

menunjukkan hasil yang hampir sama, yaitu dari Bulan Juni sampai Bulan Oktober mengalami naik-turun seperti yang ditunjukkan pada Gambar 7. Hal tersebut dikarenakan terdapat tweet yang mengandung topik diluar bahasan COVID-19. Aktivitas bermedia sosial Twitter oleh masyarakat Kota Surabaya juga menjadi salah satu alasan tinggi rendahnya perhatian publik.

Hasil analisis secara manual pada dataset yang ada menunjukkan bahwa perhatian publik Kota Surabaya fokus pada beberapa topik seperti pandemi COVID-19, kondisi lalu lintas maupun kejadian lainnya yang terjadi pada rentan waktu antara Bulan Juni sampai Bulan Oktober. Hasil pemantauan perhatian publik menunjukkan bahwa perhatian publik terhadap COVID19 tertinggi terjadi pada Bulan Juni. Jika dilihat pada Gambar 7, penurunan drastis terjadi pada Bulan Agustus. Hal ini dikarenakan pada Bulan Agustus tweet lebih banyak terkait perayaan kemerdekaan Republik Indonesia. Sehingga, tweet non COVID-19 lebih banyak dari tweet terkait COVID-19. Namun, perhatian publik terhadap pandemi COVID-19 mengalami sedikit peningkatan pada Bulan September. Dan mengalami penurunan sedikit pada Bulan Oktober. Hal tersebut dipengaruhi oleh beberapa faktor seperti banyaknya kejadian lain yang terjadi pada bulan tersebut sehingga mengakibatkan fokus publik lebih mengarah ke topik lainnya.

Pada awal pandemi COVID-19 dikonfirmasi masuk ke Indonesia khususnya Kota Surabaya, banyak perubahan perilaku publik yang merugikan satu sama lain seperti terjadinya panic buying pada bahan sembako dan lain sebagainya. Sehingga, hasil dari pemantauan perhatian publik setiap bulannya ini dapat digunakan oleh pihak terkait untuk membuat suatu kebijakan dan membangun strategi tanggap darurat yang tepat dalam menghadapi perubahan perilaku publik sebagai efek pandemi. Ujicoba menunjukkan bahwa hasil klasifikasi dengan akurasi tertinggi mencapai $97.86 \%$ dan terendah sebesar 93.63\%. Sesuai dengan hasil klasifikasi, perhatian publik paling tinggi pada Bulan Juni, sedangkan penurunan perhatian publik terhadap pandemi COVID19 yang paling drastis terdapat pada Bulan Agustus. Hal tersebut dikarenakan fokus publik terbesar Bulan
Agustus pada perayaan Kemerdekaan Republik Indonesia. Sehingga tweet mengenai pandemi COVID19 lebih sedikit.

\section{Kesimpulan}

Pemantauan perhatian publik terhadap pandemi COVID-19 dapat dilakukan melalui media sosial Twitter. Namun, teks Twitter memiliki topik yang bervariasi sehingga dibutuhkan proses klasifikasi agar dapat fokus pada satu topik tertentu yaitu pandemi COVID-19. Metode klasifikasi yang digunakan adalah variasi metode word embedding (Word2Vec dan fastText) dan variasi deep learning (CNN, RNN, LSTM). Percobaan dilakukan dengan tiga skenario yang dibedakan oleh jumlah data train. Hasil ujicoba menunjukkan bahwa semakin banyak data train maka hasil klasifikasi semakin baik. Arsitektur yang paling cocok adalah kombinasi fastText dan LSTM. Hal ini dikarenakan metode LSTM lebih unggul bila digunakan untuk model deret waktu yang dimiliki oleh teks Twitter. Sedangkan, metode word embedding yang paling cocok adalah fastText. Hal tersebut karena kinerja fastText yang menunjukkan apabila suatu kata tidak muncul selama training model, maka kata tersebut dapat dipecah menjadi $n$-gram agar vektor dari kata dapat keluar. Hasil pemantauan perhatian publik menunjukkan bahwa pada Bulan Juni perhatian publik terhadap COVID-19 mencapai prosentase tertinggi pada rentan waktu antara Bulan Juni sampai Bulan Oktober.

Pengerjaan selanjutnya adalah pemantauan perhatian publik terhadap pandemi COVID-19 dilakukan dengan lebih memfokuskan pada beberapa topik spesifik yang berkaitan dengan COVID-19 berdasarkan hasil klasifikasi dengan akurasi terbaik. Sehingga, proses klasifikasi tidak hanya untuk membagi data COVID-19 dan non COVID-19, namun juga klasifikasi untuk membagi data COVID-19 ke beberapa topik spesifik terkait COVID-19.

\section{Daftar Rujukan}

[1] Yan, L., and Pedraza-Martinez, A.J., 2019. Social Media for Disaster Management: Operational Value of the Social Conversation. Production and Operations Management Society. 28 (10), pp. 2514-2532

[2] Fahmi U., and Wibowo, C.P., 2017. Ruang Publik Online: Sebuah Dimensi Baru Dalam Proses Pembuatan Kebijakan? (Studi Kasus Penggunaan Twitter Di Indonesia). International Seminar: Reconstructing Public Administration Reform to Build World Class Governmentn. Jakarta, Indonesia, August 2017. Lembaga Administrasi Negara: Indonesia.

[3] Duli, M.R., 2018. Analisis Konten Interaksi Pengguna Twitter pada Masa 100 Hari Pertama Pemerintahan Baru DKI Jakarta Menggunakan Text Mining Content Analysis on Twitter Users Interaction within First 100 Days of Jakarta's New Government by Using Text Mining. Jurnal Pekommas, 3m (2) pp.137-142.

4] Abdurrahman, M.S., 2018. Twitter dan Ruang Publik Pemerintahan Lokal yang Partisipatif (Telaah atas Komunikasi Politik Ridwan Kamil Melalui Twitter). Jurnal Penelitian Komununikasi dan Pembangunan, 15 (2), pp. 152-168.

[5] Rathod, T., and Barot, M., 2018. Trend Analysis on Twitter for 
Predicting Public Opinion on Ongoing Events. International Journal of Computer Applications, 180 (26), pp. 13-17.

[6] Vieweg, S., Hughes, A.L., Starbird, K., and Palen, L., 2010. Microblogging During Two Natural Hazards Events: What Twitter May Contribute to Situational Awareness. In: Association for Computing Machinery-SIGCHI, Conference on Human Factors in Computing Systems - Proceedings. Atlanta, Georgia, USA 10-15 April 2010, Association for Computing Machinery: United States.

[7] Boukil, S., Biniz, M., El-Adnani, F., Cherrat, L., and El Moutaouakkil, A.E., 2018. Arabic Text Classification using Deep Learning Technics. International Journal of Grid and Distributed Computing, 11 (9), pp. 103-114.

[8] Calix, R.A., Gupta, R., Gupta, M., and Jiang, K., 2017. Deep Gramulator: Improving Precision in the Classification of Personal Health-Experience Tweets with Deep Learning. In: IEEE Computer Society, IEEE International Conference on Bioinformatics and Biomedicine (BIBM). Kansas City, MO, USA 13-17 November 2017. IEEE: USA.

[9] Kim, Y., 2014. Convolutional Neural Networks for Sentence Classificatio. In: Association for Computational Linguistics, Proceedings ofthe 2014 Conference on Empirical Methods in Natural Language Processing (EMNLP). Doha, Qatar 25-29 October 2014. Qatar: Doha.

[10] Hughes, M., Li, I., Kotoulas, S., and Suzumura, T., 2017. Medical Text Classification using Convolutional Neural Networks. Studies in Health Technology and Informatics. April 2017.

[11] Severyn, A., and Moschitti, A., 2015. UNITN: Training Deep Convolutional Neural Network for Twitter Sentiment Classification. In: Association for Computational Linguistics, Proceedings of the 9th International Workshop on Semantic Evaluation (SemEval 2015). Denver, Corolado, June 2015. Association for Computational Linguistics: Corolado.

[12] Kim H., and Jeong, Y., 2019. Sentiment Classification Using Convolutional Neural Networks. Applied Sciences MDPI, 9 (11), pp. $1-14$.

[13] Cho K., et al, 2014. Learning Phrase Representations using RNN Encoder-Decoder for Statistical Machine Translation. In: Association for Computational Linguistics, Proceedings of the 2014 Conference on Empirical Methods in Natural Language Processing (EMNLP). Doha, Qatar, October 2014. ACL: Qatar.

[14] Du, C., and Huang, L., 2018. Text Classification Research with Attention-based Recurrent Neural Networks. International Journal of Computers Communications \& Control, 13 (1), pp. $50-61$.
[15] Lai, S.,Xu, L., Liu, K., and Zhao, J., 2015. Recurrent Convolutional Neural Networks for Text Classification. In: Association for the Advancement of Artificial Intelligence, Proceedings of the Twenty-Ninth AAAI Conference on Artificial Intelligence. Austin, Texas USA, 25-30 January 2015. The AAAI Press: California.

[16] Zhou, C., Sun, C., Liu, Z., and Lau, F.C.M., 2015. A C-LSTM Neural Network for Text Classification. Cornell University, arXiv: 1511.08630 .

[17] Tholusuri, A., Anumala, M., Malapolu, B., and Jaya Lakshmi, G., 2019. Sentiment Analysis using LSTM. International Journal of Engineering and Advanced Technology, 8 (6), pp. 1338-1340.

[18] Rao, A., and Spasojevic, N., 2016. Actionable and Political Text Classification using Word Embeddings and LSTM. Cornell University, arXiv: 1607.02501.

19] Wang, B., Wang, A., Chen, F., Wang, Y., and Kuo, C.C.J., 2019. Evaluating Word Embedding Models: Methods and Experimental Results. APSIPA Transactions on Signal and Information Processing, 8, pp. 1-13.

[20] Mandelbaum A., and Shalev, A., 2016. Word Embeddings and Their Use In Sentence Classification Tasks, arXiv:1610.08229, pp. 1-16.

[21] Lilleberg, J., Zhu, Y., and Zhang, Y., 2015. Support Vector Machines and Word2vec for Text Classification with Semantic Features. Proceedings of 2015 IEEE 14th International Conference on Cognitive Informatics and Cognitive Computing, $I C C I^{*} C C$ 2015. Beijing, China, 6-8 July 2015. IEEE: United States.

22] Kuyumcu, B., Aksakalli, C., and Delil, S., 2019. An automated new approach in fast text classification (fastText): A case study for Turkish text classification without pre-processing. In: Association for Computing Machinery, ICSEB 2019: Proceedings of the $20193 \mathrm{rd}$ International Conference on Software and e-Business. Tokyo, Japan, December 2019. Association for Computing Machinery: United States.

[23] Khattak, F.K., Jeblee, S., Pou-Prom, C., Abdalla, M., Meaney, C., and Rudzicz, F., 2019. A survey of word embeddings for clinical text. Journal of Biomedical Informatics X, 4, 100057.

24] Dabiri, S. and Heaslip, K., 2018. Developing a Twitter-Based Traffic Event Detection Model using Deep Learning Architectures. Expert Systems with Applocations, 118, pp. 425439

[25] Zhang, Z., He, Q., Gao, J., and Ni, M., 2017. A Deep Learning Approach for Detecting Traffic Accidents from Social Media Data. Transportation Research Part C: Emerging Technologies, 86, pp. $580-596$. 